This article was downloaded by: [Memorial University of Newfoundland] On: 29 January 2015, At: 14:56

Publisher: Routledge

Informa Ltd Registered in England and Wales Registered Number: 1072954

Registered office: Mortimer House, 37-41 Mortimer Street, London W1T 3J H, UK

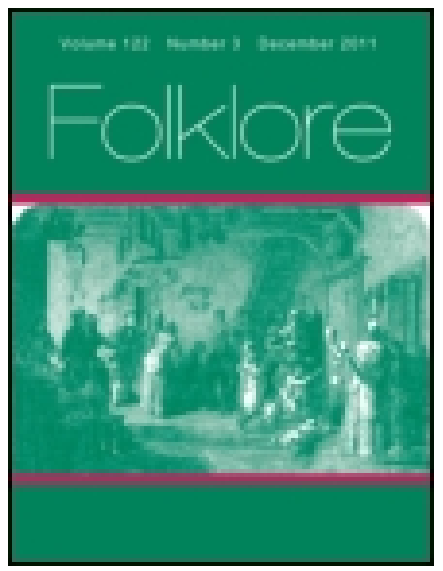

\title{
Folklore
}

Publication details, including instructions for authors and subscription information:

http:// www. tandfonline.com/loi/ rfol20

\section{Magic Songs of the Finns. IV}

J ohn Abercromby

Published online: 14 Feb 2012.

To cite this article: J ohn Abercromby (1892) Magic Songs of the Finns. IV, Folklore, 3:1, 49-66, DOI: 10.1080/0015587X.1892.9720089

To link to this article: http:// dx. doi. org/ 10.1080/0015587X.1892.9720089

\section{PLEASE SCROLL DOWN FOR ARTICLE}

Taylor \& Francis makes every effort to ensure the accuracy of all the information (the "Content") contained in the publications on our platform. However, Taylor \& Francis, our agents, and our licensors make no representations or warranties whatsoever as to the accuracy, completeness, or suitability for any purpose of the Content. Any opinions and views expressed in this publication are the opinions and views of the authors, and are not the views of or endorsed by Taylor \& Francis. The accuracy of the Content should not be relied upon and should be independently verified with primary sources of information. Taylor and Francis shall not be liable for any losses, actions, claims, proceedings, demands, costs, expenses, damages, and other liabilities whatsoever or howsoever caused arising directly or indirectly in connection with, in relation to or arising out of the use of the Content.

This article may be used for research, teaching, and private study purposes. Any substantial or systematic reproduction, redistribution, reselling, loan, sub-licensing, systematic supply, or distribution in any form to anyone is 
expressly forbidden. Terms $\&$ Conditions of access and use can be found at http://www.tandfonline.com/page/terms-and-conditions 


\title{
MAGIC SONGS OF THE FINNS.
}

IV.

\author{
XXXIV.-ORIGIN OF TIIE EARTII-GOBLIN (SKIN \\ ERUPTION).'
}

(a.)

\begin{abstract}
1 RASH (maahinen) is from the earth by birth, a red A spot upon the skin is from the courtyard, from the animosity of the earth or of the water, or from hidden poison of a frog. From this the cunning one has been brought forth, the deceitful one of the earth has been bred; although I do not the least know how it should have come here, how it should have broken out on a human skin, on the body of a woman's son; to burn it like fire, to scorch it like fiame, or as a 'snail' or a 'worm', or as some other earth-goblin would do. A worm has short legs, an earth-goblin's are still shorter. If thou hast risen from the earth, then I conjure thee into the earth. If, feeble one, thou hast issued from water, then tumble into the water. If thou hast issued from fire, then plunge into the fire. When thou art departing carry away thinc animosity, take away thine own mischicf.
\end{abstract}

(b.)

A water Hiisi rowed along, a young creature kept seesawing in a copper boat with tin oars. He reached land

1 Maahinen, see Castrén, Vorlesungen über d. Finn. Mythologie, p. 169. The remainder of these magic songs will be given in prose. Words in single inverted commas are epithets, and not to be taken quite literally.

vOL. IIt.

$\mathbf{E}$ 
like a strawberry, ${ }^{1}$ tumbled down like a lump of wheaten dough. Hence arose the breed of earth-goblins, hence hast thou, deccitful wretch, originated. Now I conjure thec away. There is no place for thee here; thy place, carth-goblin, is in the carth; thy place, water-devil, is in the water.

\section{xxxy.-Origin of Stitcil and Pleurisy.}

Formerly a lovely oak grew, an incomparable shoot shot up. It grew extremely high, sought to touch the sky with its head, hindered the clouds from moving, the fleecy clouds from scudding, and darkened half the sun, bedimmed a third of the earth.

The young men deliberate, the middle-aged ponder how they can live without the moon, how exist without the sun in these wretched borderlands, these miserable northerm lands.

They needed someone to fell, to lay low the mischicvous oak. They searched and found none, they sought and discovered no onc. Among this people in our land, among the fully-grown, among the crowd of men, there was none to lay low the mischicvous oak, to fell the straight and lofty trce.

A swarthy fellow emerged from the sca, a full-grown man from the surge, neither great nor small, but a fullgrown man of medium size, as tall as a straightened thumb [var. as thick as a summer gadfy], the height of three fingers [ $v$. of an ox-hoof]; on his shoulder lay an ornamented axe with an ornamented haft; on his head he wore a tall hat of flagstone, on his fect shoes of stone. Well, that man had a mind to fell the oak, to shatter the hellish (rutimon) trce.?

2 Red in the face like a strawberry from the exertion, but with allusion to the redness of rash and other such skin-diseases.

Sec note 4, Folk-Lore, 1, No. 3, p. 339. 
He advances with tripping gait, approaches with deliberate steps, advanced to the foot of the tree to break down the huge oak. He struck the trec with his axe, dealt it a blow with its level edge. He struck once, twice, and a third time struck a blow. Fire spirted from the axc, flame escaped from the oak.

Some chips of the tree whirled down suddenly, some fragments suddenly came wobbling down upon a namcless meadow, upon a land without a knoll. Other chips scattered, widely dispersed themselves upon the clear and open sea, upon the wide and open main.

Just at the third stroke he cut through the oak, broke the hellish trec, suddenly overturned the thriving tree, so that the root-end gaped towards the east and the branching head fell towards the west across the Pohjola river to serve as an eternal bridge for any traveller to pass to gloomy Pohjola.

A chip that had wobbled down, that had been flung on the waters of the sea, upon the clear and open main, upon the illimitable waves, did the wind rock to and fro, did the restless ocean toss about. A wave wafted it ashore, the breakers of the sea stecred it into a nameless bay, into one unknown by name, where the Hiisi folk reside, where the cvil people hold their salcs.

Hiisi's iron-toothed dog, that ever runs along the shore, chanced to be coursing on the beach, making the gravel rattle. He spied the chip in the waves, snapped it up and carried it to a maiden's hands, to the finger-tips of Hiisi's damsel.

The maiden looks at it, turns it over, and pronounced the following words: "Something might come of it if it were in the smithy of a smith, in the hands of a craftsman. From it a wizard might get arrows, an archer many instruments."

A fiend chanced to overhear, an evil one to observe her. The evil one carried the chip to a smithy, makes arrows, prepares blunt-headed arrows of it to become stitch and 
pleurisy in men, sudden sickness in horses, "sharp spikes in cattle.

The devil makes arrows, sharpens spikes inside a stecly mountain, a rock of iron. He made a little pile of shafts, a heap of heavy arrows inside a doorless, windowless smithy. He makes the heads of stecl, turns the shafts out of wood from a bough of the 'ficry' oak, from a sharp spike of the red'trec. He smoothed his arrows and feathered them with the small plumes of a swallow, with the tailfenthers of a brindled bird. Whence did he get the binding thread? He obtained the binding thread from the locks of Iliisi's damscl, from the hair of a melancholy creature. After feathering the arrows, with what were they cnerusted? With the poison of a viper, with the venom of a black snake. Then he selected his best bow and attached a string to it made from a wanton stallion's tail, from the hair of a full-grown animal.

He scized the 'ficry' bow, stretched the 'fiery' crossbow against his left knce, under his right foot. He took the swiftest arrow, selected the best shaft, straightened the 'ficry' crossbow against his right shoulder, and shot the first arrow alort above his head into the azure sky, into a long bank of cloud. The sky was like to split, the acrial vault to break, portions of the air to rend, the acrial canopy to bend at the anguish caused by the 'fiery' arrow, by the sharp spike of Aijö's son. The arrow receded where naught was cver heard of it again.

Then he shot a sccond arrow into the earth below his fect. The earth was like to go to Mana [v. to ignite], the hills to powder into mould, the sandy ridges to split, the sindy heaths to break in two from the anguish caused by the 'ficry' arrow, from the burning pain caused by the red wood. That arrow constantly receded where naught was ever heard of it again.

1 Further on, in $f(c)$, the oak is called the murderous tree, so possibly 'red' means the blood-stained trce, alluding to the bloody work effected by she arrows made from it. 'Fiery'-terrible. 
Immediately he shot a third, a final and malignant arrow, across land and swamp, across deep gloomy lorests against a steely [v. silver] mountain, against an iron [ $v$. stony] rock. The arrow rebounded from the stone, recoiled against the rock, and entered a human skin, the body of a wretched man.

Such a shaft may be extricated, such an arrow withdrawn always by virtue of the word of God, through the Lord's grace.

Of old a lovely oak grew, a flourishing sapling uprose on the shoulder of a sandy ridge, on the crest of a golden hillock. Its boughs were somewhat bushy, its foliage somewhat ample. Its branching head reached the sky, its leafy boughs spread through the air, concealed the rays of the sun, obscured the rays of the moon, prevented the Great Bear from stretching and the stars of heaven from moving.

A shiver comes over cattle, a horror over fish in the water, a strangeness over birds of the air, and weariness over human beings, for the dear sun no longer shines, nor does the moonshine diffuse light upon these wretched ones, these unfortunates.

They searched for a man, sought for such an one that could break down the oak, fell the splendid lofty trec, prostrate the lively tree, clear away the hellish (rutimon) tree. None was found to clear away, to smash the brittle tree to bits. There was no strong doughty man in our own land, in plcasant Finland, in beautiful Karelia to do this ; nor did one come from further aficld, from daring Sweden, from weak Russia, nor from the disputed ground of this realm, that could fell the oak, fracture the hellish tree, prostrate the hundred-headed oak.

A [v. small, $v$. black, $v$. old, $v$. iron] man emcrged from the sea, a full-grown man uprose from the waves. He was not very large nor very small; his height was quarter-ell 
[v. an cll], a woman's span ; he could lic down under a bowl, stand under a sicve. His hair reached down behind to his hecls, his beard descended in front to his knecs. On his nape was an iron hat, on his fect were iron boots, on his arms were iron slecves, on his mitts was iron cmbroidery; an iron belt begirt his waist, behind the belt was an iron axe provided with an iron haft, at the end of which was an iron knob.

- IIe sharpens his axe, whetted its level edge on a rock of iron, on a mountain tipped with stecl, on five Esthonian whetstones, on six whetstones, on the sides of seven hones, on cight surfaces; by night he grinds the axc, by day he fashions the haft.

lly degrees the axe became sharpened, the haft was gradually fashioned. Alrcady a full-grown man had become full grown, the man had begun to be a man. His foot moves proudly on the ground, his head touches the clouds, the bristles of his beard shone like a leafy grove upon a slope, his hair shook about like a clump of pines upon a hill.

He advances with tripping step, approaches with unstcady gait, clad in wide brecches, a fathom wide at the foot, onc-and-half at the knce, and two fathoms at the hips. Once and again he stepped, making an effort to approach the oak. One foot he stamped down upon a spot of yiclding sand, with the other he trod upon the livercoloured carth. Already with the third stride he reached the roots of the oak, the barbs and endless torments of the red trec.

Ile struck firmly with his level-cdged axe against the oak; from the trec's side a chip flew off, an outside chip splintered off which the wind carried to the great open sea to scrve as a boat for Väinämöinen, as wood for the singer's skiff. Once and again he struck a blow, nor was it long before he felled the oak trec to the ground with its crown towards the south, the root-end towards the north-east inclining due north. 
He contemplates the chips on the spot where the red tree was felled, where the wide spreading oak lay, and thus expressed himself in words : "One might get useful wood from these branches of the level-headed oak. Whocver takes a branch has obtained eternal luck, whoever severs a heavy bough has severed an eternal power to inspire love, whocver breaks off a topmost branch has broken off eternal magic skill."

The chips that had scattered, the splinters that fell in such a way as to be drifted about on the clear open main, were driven by a wave, were tossed by the ocean-swell, were jolted by a gust of wind, were floated ashore by the water to the end of a long promontory [ $v$. to Tuoni's black river] to the beach of an evil pagan.

Hiisi's tiny little lass, a woman of fair complexion, was washing dirty linen, besprinkling ragged clouts at the end of a long gangway, on the top of a great landing-stage. She scized the chips, split them into splinters, cut them into chips for cow-litter, gathered them into her wallet, carried them in her long thonged wallet to the courtyard at home. Here she snatched up the chips in her pouch and upsets them about the house.

Three of her brothers are at home, who interrogate her about this: "What might a wizard get from these, what would an elf-smith (Keito) hammer out?" The maiden thus expressed herself: "A craftsman will get something, a man of skill will forge something, a wizard will obtain wood for arrows, Lempo will get leaf-headed spears and Sudden Death pleurisics."

Hiisi [ $v$. the devil] chanced to overhear, an evil one to observe this. He sent his son to a smithy to hammer out arrowheads, to forge spears. The laddie went to the smithy, makes arrows, hammers out blunt arrowheads, prepared a little pile of bolts, a heap of heavy arrows. He forged a dozen pikes, made a bundle of spears from the branches of the 'fiery' oak, from the hard spikes of the red tree. He made them neither great nor small, he made 
the spears of medium size, with which he stabbed a hundred men, kept pricking a thousand.

The devil took up his pricking-tools, Kcito scized the spear, kept brandishing his spears, launched angrily his sharp spikes, which come as stitch and pleurisy to men, as sudden sickness to kine. Hiisi cares nothing where he has shot his arrows, whether into a beast with horns, or into a neighing horse, or clse into a human skin, into the body of a woman's son.

(c.)

Formcrly a great oak grew, a sapling without a blemish sprang up. The oak was of an cvil sort, with its broad head it hid the sun, encompassed the moon with its foliage, the Great Bear with its branches.

To live without light is hard and wearisome for human beings, when the sun never shines, when there is no moonshine. No man, no mother's son came forward of the rising gencration, or indeed of the old men, that could fell the oak, could break down the murderous tree. There was none in our native land, in these wretched borderlands between the two Karclias, a land disputed by three kingdoms.

They made a search through the country in five parishes, in six church districts. But as no one was found they made inquiry in heaven. An old man came from heaven to all appearance fit. His chest was a fathom wide, the hat he wore was a fathom wide, the drawers upon his legs were two fathoms wide. On his shoulder rested a golden axe with a golden handle, at the end of which was a silver knob.

Hc looks about him, turning here and there. With one foot he stepped to the edge of a willow-bush, with the other he advanced to the root of the sappy oak. He hacked the sappy oak, kept slashing at the level-topped trec, strikes off the top castwards, casts the root-end northwestwards. Every chip of it that he cut off became a water-lily leaf, every branch that he strewed around got 
lost in the sca, to be drifted by waves, dashed about by the breakers.

A cur dog of the shore appeared, one that used to run by the riverside. It ran from stone to stone, it sprang from one fir branch to another, saw something black upon the sea, picked it up, and gave it into an elf-smith's (Keito) hands, into the fingers of a hideous man. The elf-smith grasped it in his hands, looked at it, turned it.over: "Why, arrows might be made of this, blunt-headed arrows might be fashioned."

He smoothed a pile of shafts, a heap of triply-plumed arrows out of what had been broken off the oak, had been splintered off the brittle tree. Each onc that he finished his sons feathered with the tiny plumes of a bullfinch, with the feathers of a sparrow's wing, with the bristles of a boar, with the shaggy down of a spider.

The cvil one has three sons, one a cripple, the second lame, and the third stone-blind. The cripple strings the bow, the lame one holds the arrows, the stone-blind one shoots. The cripple strung the bow and gave it into the archer's hand. The stone-blind archer makes trial of his arrows near swamps and solid ground, near long farmyards. He shot a singly-feathered arrow aloft into the sky, into the oozy clouds, into the swirling, feecy clouds. The sky shattered into holes, the atmosphere into apertures. He himself uttered these words: "The arrow has whizzed somewhere whence it will never return, nor is that by any means specially desired."

He shot a doubly-feathered arrow into the ground below his feet. The carth below suddenly splits, its mould instantancously fissures, all at once strong boulder-stones give a crash, and stones upon the shore rend. The arrow whizzed somewhere whence it will never return.

He shot a triply-feathered arrow at the hill of Pohjola [ $v$. Hiitola], against the lofty mountain, against the wooded [ $v$. iron] hill. He shot so that it deflected from the stone, glanced sideways off the rock, rebounded from the stone, 
recoiled from the rock. Then it wanted to strike animals, to enter a human skin, the body of a woman's son; but there is no place for it there whence it may return.

A 'ficry' oak grew on a 'ficry' plain. A boy came from Pohjola, a full-grown man from the cold village, trailing behind a small hand-sledge on which lics a little axe with a haft an cll long, with an edge a span high; the edge is new, the haft old. On his hands he wears new gloves worked with old embroidcry. IVith his hands he began to batter the 'ficry' tree, to smash the 'sparkling' onk. He hewed it into splinters, cut it into chips, into litter for cows. $A$ wind carried them to sea to be drifted by the sen waves to Tuoni's dark river, to the underlake of Manala. From them a wizard gets arrows, a devil pricking instruments.

The devil manufactures arrows, Lempo leaf-headed spears from branches of the 'ficry' oak, from splinters of the cvil trec in a doorless, windowless smithy. An arrow from the devil, a leaf-headed spear from Lempo whizzed into a wretched human being's skin, into the body of onc born of a woman.

Udutar (daughter of Mist), Nature's daughter, Terhetar (d. of log), the sharp girl sifted mist with a sicve, kept scattering fog at the end of a misty promontory, at the extremity of a foggy island; from which circumstance burning pains have their origin, burning pains and plcurisics, in a naked skin, in a body racked with pain.

\section{XXXVI.-SWELLING ON TIE NECK.}

Strange swelling I Lempo's lump I I know your family, from what, cxerescencel you originated, from what, horror of the land I you were bred, out of what, 'whorl of Lempo l' you wcre spun, out of what, ball of Lempol you swelled 
up on the place where breath is breathed, on the narrow muscles of the neck. Your family is from the mist, ${ }^{1}$ your mother is from the mist, your father from the mist, your ancestor is from it, your five brothers are there, the six daughters of your godfather, your paternal uncle's seven children. Pray remove yourself to namcless meadows unknown by name.

\section{XXXVII.-TIE ORIGIN OF THE TOOTII-WORM.}

(a.)

You fidgety, globular being! the size of a sced of flax, looking like a flax-seed, that destroys the tecth, kecps cutting the jaw-boncs, I know, indecd, your family, and all your up-bringing. A black [v. iron] man cmerged from the sea, from the waves uprose a full-grown man, the height of a straightened thumb, the stature of a man's finger. A single hair comes wafted by the wind. A beard grew from the hair, and on the beard was engendered a worm. Owing to this the low wretch came, the evil pagan removed into the beloved jaw-bones, the dearlycherished tecth, to devour and gnaw, to crunch, rasp, and play havoc with the jaws, and hack the tecth.

There now is your family, there is your likeness.

A furious old quean [ $v$. Väinämöinen's old wife], the stout woman Luonnotar [v. sturdy old Väinämöinen], set to work to sweep the sca, to mop the billows with a broom, wearing on her head a textile of sparks, with a cloak of foam over her shoulders. She swept a whole day, swept the next day, forthwith swept a third whole day. The refuse gathered in her broom, in her copper besom. She was anxious to remove it, so she raised the besom from the waves, made the copper handle twirl high above her

'Or, "from Sumu", regarding it as a place-name. 
head. The refuse stuck fast in the besom, so she seized it with her tecth, whercupon an aching pain scized her tecth, a full-grown devil her jaw. Hence that evil one [v. cannibal] was bred, that biter of bone came to close quarters, that kecps rustling in the jaw-bonc, that hacks the teeth, digs into the whole head, and kceps gnawing at the members.

\section{(c.)}

The stout woman Luonnotar, the furious old quean, went to find a broom in a leafy grove, to get material for a besom in a copse. $\Lambda$ pin fell from her bosom, a copper pin dropped suddenly, fell rustling into the withered grass, with a jingling noise into the hay. Hence the worm was bred, henee in the dearly-cherished tecth, in the unfortunate check-bones originated Tuoni's grub that cats bone, bitcs flesh, and plays havoc with the tecth.

\section{(d.)}

A blind girl of P'ohjola, Väinämöinen's old scrvant-girl, was dusting his small chamber, was swecping the floor, when a picec of dirt fell from the broom, a twig snapt of the besom upon the swept floor, upon the dusted boards, near the seams of the planks. Hence the devourer originated, henee the gnawer was bred which shot itself into a mouth, then slid down upon the tongue and stumbled forwards to the tecth, in order to feed upon the bloodfilled flesh, to rack with pain the blood-filled bones.

(c.)

The cvil housc-mistress, Syöjätïr, iron's old housc-mother, Rakchetar (Hailstonc's daughter), pulverised grains of iron, hammered stecl points upon an iron rock in an alder-wood mortar with a pestle of alder-wood in a room built of alder-wood. She sifted what she had pounded, and gobbled up those 'groats' of hers. Bits ivent astray among the tecth and settled themselves in the gums, in order to hack the tecth, to rack the jaw-bones with pain. 


\section{$(f)$}

A wee man emerged from the sca with a tiny axe in his hand and a little billhook under his arm. He cncountered an oak upon the path, a gigantic tree upon the shore. He struck the tree with his axe, dealt it a blow with the level cdge. A chip stuck very firmly to the axe. With tooth and nail he tried to detach it. Then the obstruction stuck in his mouth, an aching pain took possession of his tecth, a stench diffused itself in his jaws. Hence the great devourer, the evil hacker of the teeth originated.

\section{(s.)}

A fox carried off and crunched a fragment of bone as he ran along between two rocks, along the slopes of five mountains. Hence, indeed, the worm was bred, hence originated Tuoni's grub, that spread itself as far as the jaws, and played havoc with the teeth.

\section{XXXVIII.-THE ORIGIN OF CANCER AND WHIte Swellings.}

Cancer was born in Cottage Creck, at the mouth of the Jordan river. Harlots rinsed their linen caps at the mouth of the Jordan. Hence, then, a cancer was bred, henec the bone-bitcr made its appearance that bites bone, cats flesh, sucks blood raw without its being cooked in a pot, without its being heated in a copper. The 'dog' set off to run about, the 'worm' began to crawl; went to corrupt bone, to macerate flesh, to make it suppurate, to cause it to swell in the shape of boils and white swellings.

\section{XXXIX.-The Origin OF Ale.}

\section{(a.)}

The origin of ale is known, the first beginning of drink is gucssed. The origin of ale is from barley, of the noble 
drink from hops, though it is not produced without water nor $y c t$ without firc.

Hops, the son of Boistcrous (Remunern), was poked, was ploughed into the ground as a small snake, as an ant ${ }^{1}$ was thrown down at the side of the well of Kaleva, on the unplouglied cdge of Osmo's ficld. From it a young shoot sprang up, a green tendril uprose, which mounted into a little tree and stretched towards its head.

Osmo's [v. Luck's] old man sowed barley at the end of Osmo's ficld. The barley grew splendidly, sprouted most perfectly at the end of Osmo's new ficld, in the cleared land of the son of Kalcva.

Osmotar the brewer of alc, the woman that brews small becr, took up six grains of barley, seven clusters of hops cight ladlesful of watcr, put a pot on the fire, and brought the brew to boiling-point. She let the barlcy ale simmer for a whole summer day. She managed to boil the ale, but could not get it to ferment.

She reflects and turns over in her mind what she might add to make the ale ferment, to make the small beer work. She saw wild mustard in the ground, rubbed it with both palms, grated it with both hands against her thighs, and rubbed out a golden-breasted martin.

When she obtained it, she exclaimed: "My little martin I my pet l go where I command, into the gloomy wilds of a forest where mares are wont to fight, where stallions battle savagcly. In your hands let their froth drip, with your hands collect their lather to serve as ferment for the alc, as yeast to make the small becr work."

Thus advised, the obedient martin hurricd off at full specd, sooll had run a long distance, to the gloomy wilds of a forest where mares are wont to fight, where stallions battle savagcly. Froth dripped from a marc's mouth. slaver from a stallion's muzzle, which it brought to the woman's hand, to the shoulder of Osmotar.

1 I.e., possessing the veromous or pungent qualities of a snake or of an ant. 
The woman upset it into her small beer, Osmotar into her ale. The ale became depraved, made men deficient of sense, caused the half-witted to brawl, the fools to play the fool, the children to cry, and other folk to grieve.

The lovely maiden Kalevatar, a girl with neat fingers, brisk in her movements, ever light of foot, was moving over a seam of the planks, dancing about on the centre of the floor, when she saw a leaf upon the floor and picked it up. She looks at it, turns it over: "What would come of this in the hands of a lovely woman, in the fingers of a kindly maiden?"

She placed it in a woman's hands, in the fingers of a kindly maiden. The woman rubbed it with both her hands against her thighs, and thereby a bee was born. The bee, the lively bird, flew away at full speed, soon flew a long distance, quickly reduced the intervening space, to an island in the open main, to a skerry in the sea, to a honey-dripping meadow, to the margin of a honcyed ficld. A short interval elapsed, a very little time slipped by, alrcady it returns buzzing, making a mighty fuss, brought virgin honey on its wing, carried honcy under its cloak, which it placed in the woman's hand, in the fingers of the kindly maiden.

Osmotar thrust it into her ale, the woman into her small becr. Then the new drink began to rise, the ruddy ale to work in the new wooden vat, in the two-handled tub of birch. The ale, the extract to be drunk by men, was ready for usc.

Hops shouted from a trec; water whispered from a stream; barley from the edge of a ploughed field: "Wher shall we get together, when unite one with the other, at the feast of All-hallows (Keliri), or at Yule, or not till Eastertidc? 'Tis tedious living alone, 'tis pleasanter in twos and threcs."

The kindly maiden, the girl of Pohja [ $v$. Osmotar the 
brewer of alc], reffects and ponders: "What would happen were 1 to bring them together and unite them, causing each onc to mect the others?"

$\Lambda$ redstart sang from a trec: "A noble drink would be obtained, good ale would result from them in the hands of a skilful maker, one that rightly understands."

The kindly maiden, the girl of Pohja, plucks clusters of hops, gathered grains of barlcy, drcw water from the cddy of a stream. These she united, intermingled one with the other, and intended to brew in a new two-handled tub of birch. Stones were heated for a month, a forest of trees was burnt, water was boiled a whole summer [ $v$. a sea of water was boiled], ale was brewed for a whole winter. A wagtail [ $v$. titmousc] fetched watcr, a bec brought honey to make the new drink ferment. Owing to that the new drink fermented in the two-handled tub of birch, foamed up to a level with the handles, bubbled above the rim, was like to splutter on the ground, to fall upon the floor. Hence the violent one was known, was judged, was supposed at the proper time to pour upon the carth for the benefit of the carth before it became great.

The kindly maiden, the girl of Pohja, gave utterance to words: "Ilow unlucky I am! alas my thoughtless deeds I for 1 have brewed bad alc, have produced an intractable small becr. It has swelled up to the handles, it inundates the floor."

A redstart sang from a tree, a thrush from the eaves: "It docs not pertain to poor living, 'tis a drink that pertains to good living, that should be cmpticd into tuns, transported into cellars in oaken barrels, in butts with copper hoops."

Small Becr expressed himself cleverly, took up the word and said: "'Tis bad to live inside a half-tun behind a copper tap. If you do not provide singers, do not invite merry ones, I will spirt out foaming from the barrel, will escape from the half-tun, will kick the half-tun into two, will bang the bottom out with blows, will move to another farmhousc, 
to the neighbour's over the fence where people drink with jollity and roar with merriment."

Such was the beginning and origin of alc. From what did it obtain its good name, its famous reputation? A cat called out from the stove, a puss from the end of a bench exclaimed : "If this pertains to good living (hyvä-oloinen) may its name be ale (olut)."

Hence ale obtained its name, ${ }^{1}$ its famous reputation, as it pertained to good living, was a good drink for the temperate, gave laughing mouths to women, a checry mind to men, caused the temperate to be merry, the boisterous to stagger [ $v$. fight].

The late Professer Ahlquist ${ }^{2}$ gives a Mordvin example of "the origin of alc", which is short enough to transcribe.

"Where does hops originatc, where does hops grow? It originates in a damp spot, in a willow copse, its sced is a white pearl. The wind blew, puffed it. Whither, whither did it puff it? To the bank of a river, into a cook-house it puffed it, in the cook-house they are brewing alc. It puffed it to the cdge of a vat, where it began speaking with the rye: 'Mother Ryc, Mother Ryc, allow us who are specchless to begin to speak, us who do not fight to begin to fight, us who do not dance to begin to dance."

\section{XL-TIIE ORIGIN OF BRANDY.}

From what has brandy uriginated, from what has the lovely drink grown? Brandy has becn brought forth, the lovely drink has been produced from the beards of young

1 An example of popular etymology. The word for ale, olut, diminutive olonen, is erroneously supposed to be derived from oloinen, living, existent.

2 Aluistelmia Malkoilla Venäjällä, p. 166. vot. III. 
66

Magic Songs of the Finnts.

barley, from the bristly heads of green corn, but it is not produced without water, not yet without a raging fire. Water caused it to be lively, fire made it raging.

\section{JOIN ABERCROMBS:}

(To be continued.) 